\title{
Impact of SPS Measures Imposed by Developed Countries on China's Tea Export-A Perspective of Differences in Standards
}

\author{
Yinguo Dong ${ }^{1} \&$ Yue $\mathrm{Zhu}^{2}$ \\ ${ }^{1}$ School of Business, East China University of Science and Technology, Shanghai, China \\ ${ }^{2}$ School of Economics, Shanghai University, Shanghai, China. \\ Correspondence: Yinguo Dong, School of Business, East China University of Science and Technology, Shanghai, \\ 200237, China.
}

Received: October 5, 2015

Accepted: October 21, 2015

Available online: October 27, 2015

doi:10.11114/aef.v2i4.1175

URL: http://dx.doi.org/10.11114/aef.v2i4.1175

\begin{abstract}
Sanitary and phytosanitary (SPS) measures have become the main obstacles to some China's traditional export product like tea since China's accession to WTO. Different from previous researches, this paper approaches the problem from the perspective of SPS gap between China and importing countries. Based on the panel data of China and its 10 developed trade partners during 1992 to 2013, it applies gravity model to quantify the effects of SPS gap both in quality (i.e use Maximum Residual Limits of fenvalerate and endosulfan as proxy) and in quantity (i.e regulated numbers of Maximum Residual Limits) between China and its partners on China's tea export, the results attribute China's tea restricted by SPS measures to the big gaps from developed countries in maximal residual limits of pesticides and numbers of regulated pesticides.
\end{abstract}

Keywords: Food Safety Standard; SPS measures; Tea Exports; Maximum Residual Limits (MRLs)

\section{Introduction}

After the Uruguay round negotiations, agricultural products have been incorporated into the multilateral trade regulations. With the implementation of the Agreement of Agriculture, tariff level has been substantially cut down (Trienekens \& Zuurbier, 2008), the average global tariff on agricultural products reduced from $20.2 \%$ in 1995 to $12.5 \%$ in 2013 (Note 1). However, some emerging food safety standards, especially sanitary and phytosanitary (SPS) measures, replaced the tariff, became the main obstacles to agricultural trade (Henson et al., 2005; Disdier et al., 2008; Henson and Humphrey, 2010). During the period of 1995 to 2013, the number of WTO/SPS notifications of agricultural products increased from 131 to 655 (Note 2). This sharp increase in the number of SPS notifications indicates that the importing countries have paid great attention to food safety issues. This change also has a broad impact on export of agro-products, especially an obvious negative effect on products exporting from developing countries to developed countries (Otsuki \& Wilson, 2001; Jongwanich, 2009; Neeliah \& Goburdhun, 2010).

As a developing country, China's agro-product trade is also not exempt from the adverse influence of SPS measures (Note 3). In 2013, over 1904 batches of China's agro-products were refused or detained by the United States, Japan, EU, Canada and South Korea, the major trade partners of China (Note 4). According to the survey of China's General Administration of Quality Supervision, Inspection and Quarantine (AQSIQ, 2012), there were 50.8 percent of China's agricultural exporting firms being affected by foreign SPS measures in 2011. China's advantage varieties of agro-products such as vegetables, seafood, honey and meat have been struck by SPS measure from developed countries (Dong \& Jiang, 2012; Song \& Beghin, 2014).

China is the world largest tea producer and a major exporter. China's tea accounts for about $1 / 3$ of world production and 1/7 of world export, respectively. Since late 1990s, it has increasingly been restricted by the SPS measures in developed countries, especially EU, Japan and USA. Some studies find SPS regulation and food safety standards have become the main obstacles of tea export. Gu et al. (2007) find that pesticide residue is the main factor restraining China's tea from exporting to Germany and Japan, main destinations of Chinese tea. Sun et al. (2007), by calculating the cost of pesticides denotes that the change of EU maximal residual limits (MRLs) in 2003 increased the cost of China's tea production and decrease of China's tea export to EU. $\mathrm{Xu}$ and Gao (2006) conclude that China's tea export is significantly restricted by foreign TBT/SPS since 1999. The research by Qiu et al. (2009), applying the Granger 
causality test, shows that export scale, the domestic tea production and foreign SPS measures are the main determinants hindering China's tea export. Wei et al. (2012) measure the effects of MRLs for pesticides imposed by importers on China's tea export, and conclude that if the stringency of foreign MRLs for endosulfan and fenvalerate increase by $1 \%$, China's tea export would decrease by $22 \%$.

The exiting researches, either taking the SPS measures in importing countries as a qualitative variable (dummy) or adopting directly the maximal residue limits of pesticides in importer side into the gravity equation, study the effects of SPS on China's tea export by taking Chinese SPS measures as static factors. In fact, Chinese standards for tea are dynamic since government has made numbers of revisions in last two decades. If China has a higher control standard than its partner, then the SPS standards of importing countries will hardly stop or obstruct China's tea export, and visa verse. Clearly, it would be more interesting from a policy perspective to explore the gap of SPS measures between China and its partners and their effects on China's tea export. This paper pioneers to study the effects of the SPS difference both in quantity and quality between China and developed countries on China's tea export, aim to better understand the restriction factors and offer proactive measures to deal with the problems.

\section{Review of China's Tea Export}

Chinese tea export experiences some big changes in last two decades. First, the export grows disproportionately to the production. During 1992 to 2011, tea production grows by 5.62\% annually; and its proportion to world's total production rises from $23 \%$ to $35 \%$ (see Figure 1). In the same period, tea export increases by $3.25 \%$ annually and its share in world total keep constant (see Figure 2). According to our calculation, the average annual export growth of China's tea shows a downward trend, i.e. drops from 5.9\% during 1996 2000 to 4.5\% during 2001 2005 and further to $1.1 \%$ during 2006 2011; whereas those of China's tea production during the three periods are 2.75\%,6.25\% and 9\% (Note 5). Obviously, the growth of tea production is mainly driven by domestic consumption, rather than abroad demand.

Second, export price is lower than other competitors. From 1992 to 2011, the unit price of China's tea is not only lower than the world average for $15 \%-20 \%$, but also lower than that of major exporting countries (see Figure 3). For example, China's export price is only $65 \%$ of Sri Lanka in 2011. Relative lower export price, on one hand, might be the result of low quality or the prevalence competitive strategy. But on the other hand, it indicates that Chinese tea is just an ordinary product, rather than the active player of high-end market.

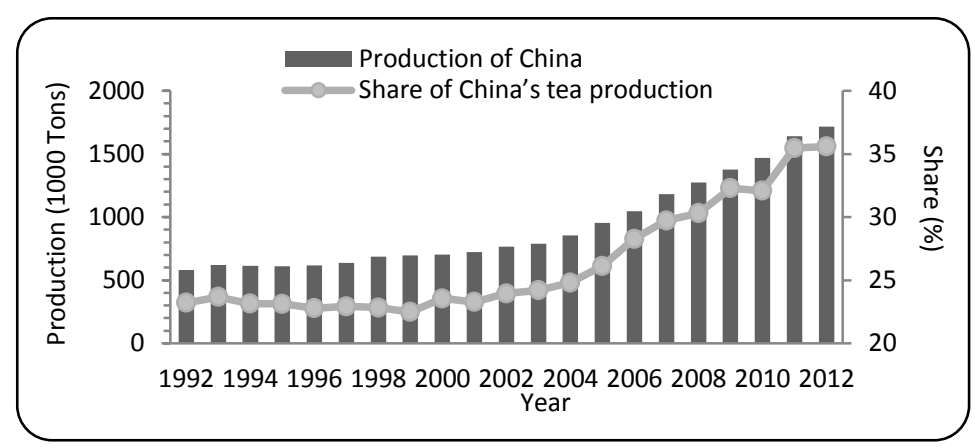

Figure 1. China's tea production and its share in world's tea production during 1992 to 2012

Data source: FAO database（http://www.fao.org/statistics）

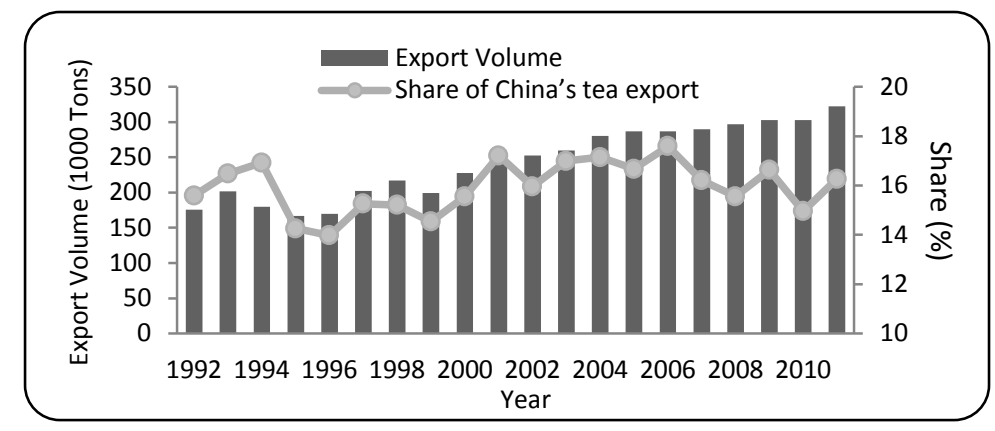

Figure 2. China's tea export and share in world's total export during 1992 to 2011

Data source: FAO database (http://www.fao.org/statistics)

Third, export destination has switched from developed countries to developing countries. There're about 200 countries and regions import tea from China in 2013 (Note 6). The top forty markets are mostly located in Africa, Europe and Central Asia, and their imports account for 95\% of China's total tea export. The top five importers in 2013 are Morocco, 
Uzbekistan, USA, Mauritania, and Japan. Only Morocco's import accounts for nearly 20\% of China's the total exports (Note 7) .The European Union used to be the major importer of Chinese tea. But after the year 2000, their imports grew sluggishly. Currently, among other developed countries, Japan is the second largest importer of China's tea. But from 2009 to 2013, its imports decreased by $1.94 \%$ annually. Due to the different growth performance, the share of developed markets in total China's tea exports fell from 51.32\% in 1996 to $22.91 \%$ in 2013(see Figure 4).

Finally, SPS regulation became the main constraint of tea export to developed markets. Since 1995, the tariff on agricultural products has dropped substantially, of which the average tariff level for China's tea declines from $22.4 \%$ in 1996 to $10.1 \%$ in 2013 , nearly a 55 percentage drop. At the same time, the notifications of SPS measures from WTO members present an upward trend (see Figure 5), especially from the EU and Japan, whose notifications account for $60-70 \%$ of all for tea.

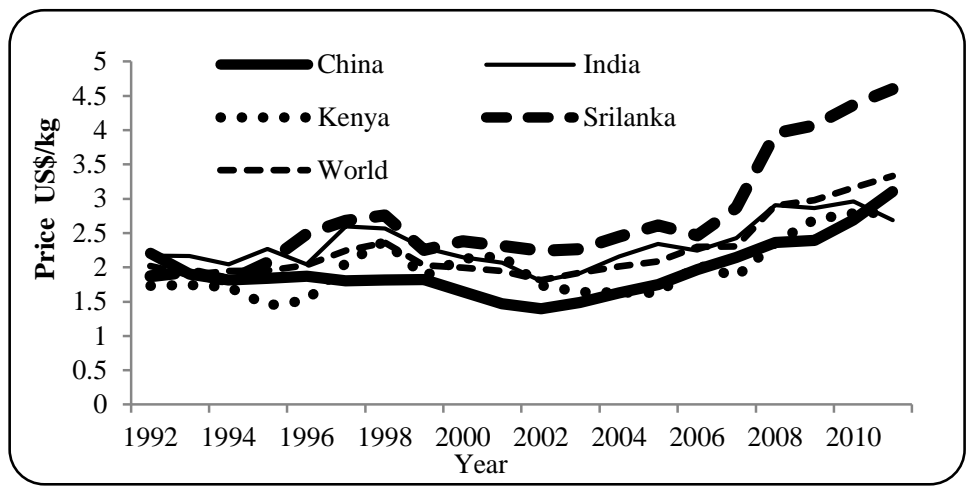

Figure 3. International comparison of tea export price

Data source: FAO database (http://www.fao.org/statistics )

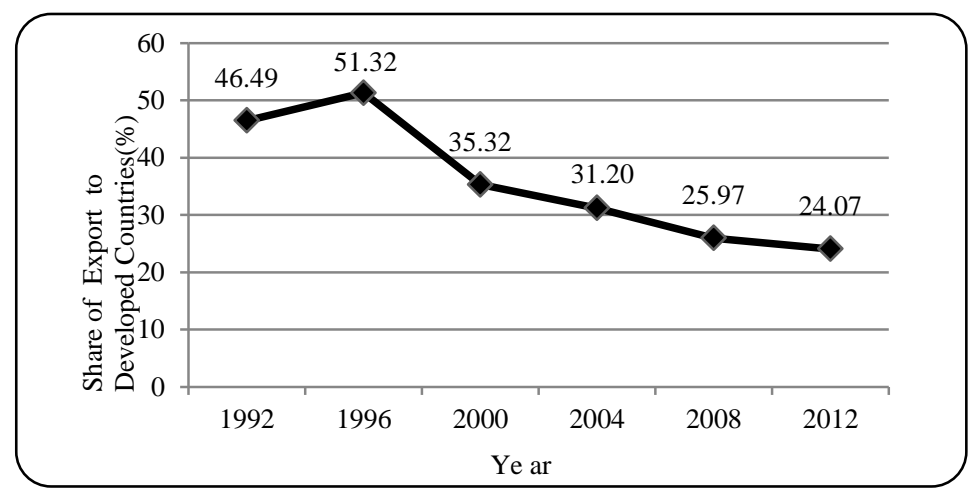

Figure 4. The change trend of the share of China's tea export to developed countries

Data source: UN trade database (http://unctadstat.unctad.org)

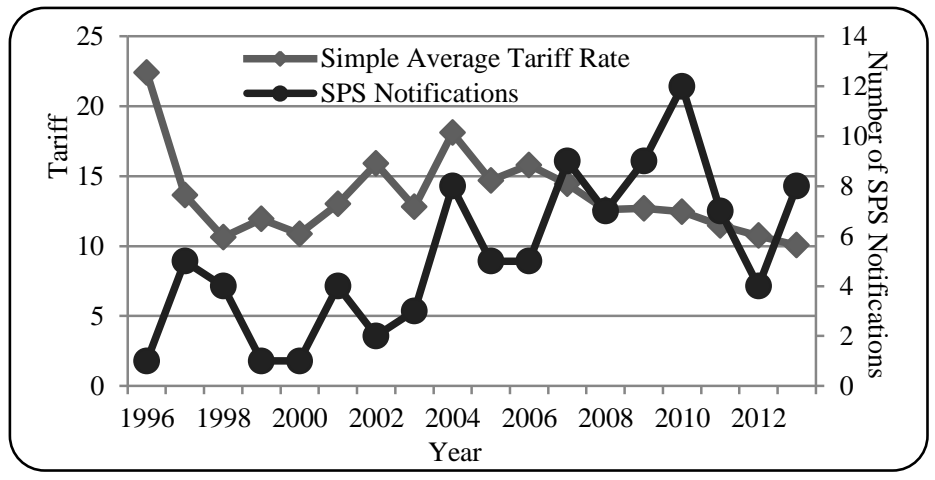

Figure 5.The tariff level for Chinese tea and the number of notifications of SPS

Source: According to calculated data from TRAINS database and SPS-IMS database of WTO.

\section{Gap in SPS standards and the Effects on Tea Export}

SPS measures include regulation, standards of maximal residue limits, inspection procedures and sampling methods. Their influence of on trade flow are through affecting the cost of compliance (Robert et al., 1999), which is defined as 
an additional expenditure paid by exporters to comply with the SPS requirements in importing countries (Henson \& Heasman, 1998). Based on the hierarchy development level, the costs of compliance for different exporters are heterogeneous. For some, the cost of compliance may exceed the compliance benefits and it will force them to exit. If more exporters fail to comply with the SPS measures in importing countries, then the exports of the country will declines. When SPS measures are beyond the capability of exporters such as lacking of facilities of compliance or human resource, they will lead to trade restriction or even de facto trade ban for exporters (Wilson \& Otsuki, 2004; Anders \& Caswell, 2009; Li, 2014).

The crucial limitation for exporters to comply with SPS is that their SPS standards are much lower or laggard than those in importing countries, i.e. the gap in control magnitude of SPS measures between importing and exporting countries (Dong \& Jiang, 2012). In general, developed countries set much higher requirements for food safety, flora and fauna as well as environment requirements owing to their higher income. So their SPS measures are much stricter than those of developing countries, whom being ruled out of the markets of developed countries due to high cost of compliance (Wilson \& Otsuki, 2004; Manarungsan et al, 2005).

\subsection{SPS gap in quantity affects the cost of compliance}

The differences of SPS measures are reflected in control scopes for risk, for example, pathogenic bacteria, veterinary drug, pesticides, pollutants, leading to uneven coverage of regulated pesticides, is defined herein as the quantity gap of SPS measures. Advanced technology in identifying hazards and their sources make them possible for developed countries to set control standards for wide-range of pesticides, or even one pesticide establish different MRLs standards on different parts of animal(head, body, and liver) or plant (root, stem, and leave). Extensive coverage of pesticide and the refinement of control standards ensure a high-level protection for food safety and environmental safety. Whereas developing countries, short of identifying technology and analyzing methods, only a small number of agro-products or just a few of pesticides are regulated. As a result, they set up less MRLs standards. Lots of food or agro-goods have no pesticide control standards, or constant MRLs are made for different products or different pesticides. When the SPS standards' number of exporting countries is less than that of importing countries, firms of exporting countries will have to bear additional cost of compliance and a high probability to be hindered by SPS. Moenius (2004) argues that the common standards or unilateral standards of exporting countries will promote bilateral trade, whereas the unilateral standards of importing countries restrict bilateral trade. Thus, we propose the first hypothesis, i.e. China's tea export is restricted by the SPS gap in quantity (i.e. number of MRLs) between China and developed countries.

\subsection{SPS gap in quality affects the cost of compliance}

The gap of SPS measures among countries is embodied not only as the coverage of hazards including infective loimia, insect invasion, biological pathogens, chemical residues and physical pollution, but also as the level of stringency of SPS. For example, consumers in developed countries are more sensitive for the risk, so their SPS standards such as maximal residue limits have low tolerance for pesticides, namely they have more intensive or stringent MRLs. Contrary to the developed countries, the consumers in developing countries, due to income constraint, are more tolerance for risk. Therefore, food safety standards in developing countries are less harsh. The heterogeneous stringency of MRLs is defined as quality gap of SPS measures in this paper. Developing countries will face high cost of compliance when their looser control standards are raised to comply with the stringent SPS ones of developed countries (Maskus et al., 2005; Chen et al, 2008). The maximal residue limits of pesticide are the major forms and main barrier of exporters from developing countries confronting, therefore the discrepancy of SPS measures are largely reflected in the gap of pesticide residue limits between developing and developed countries (Drogué \& DeMaria, 2012). As far as tea production is concerned, pesticides are commonly used to control insects and pests. If developed countries set less tolerance of pesticide residue than China, Chin's exporting firms have to bear high cost of compliance, tea exports would be hindered. Thus, the second hypothesis of this paper is the gap in MRLs of chemical between China and developed partners would restrict China's tea exports.

\section{Model Specification and Data description}

To study the effects of SPS measures on trade flows, scholars commonly introduce SPS, as a kind of factor affecting trade costs, into the classical gravity model (Otsuki \& Wilson, 2001; Wei et al., 2012,e.g.), adopting maximum residual limits (Otsuki \& Wilson, 2001; Neeliah \& Goburdhun, 2010; Dong, 2011,e.g.), HACCP standard (Anders \& Caswell, 2009; Liu \& Yue, 2012,e.g.) or SPS notification number as a proxy of SPS measures (Disdier et al., 2008; Xiong \& Beghin, 2011; Qin \& Ni, 2013). Based on the previous studies, we introduce the SPS gaps both in quantity and quality for tea between China and developed countries into gravity model, using the trade data between China and 10 major developed countries, namely, the United Kingdom, Germany, France, Italy, Netherlands, Belgium, Japan, the United States, Canada, and Australia during 1992 to 2013, to explore the impact of SPS measures differences on China's tea export. Our model express as: 


$$
\begin{aligned}
& \operatorname{Ln}\left(\operatorname{Exp}_{i t}\right)=\alpha_{0}+\alpha_{1} \operatorname{Ln}\left(G N I_{e t}\right)+\alpha_{2} \operatorname{Ln}\left(G N I_{i t}\right)+\alpha_{3} \operatorname{Ln}(D i S)+\alpha_{4} \operatorname{Ln}\left(\operatorname{Pr} o d_{t-1}\right) \\
& +\alpha_{5}\left(\text { Fen }_{e t}-F_{i t}\right)+\alpha_{6}\left(S u I_{e t}-S u I_{i t}\right)+\alpha_{7}\left(\text { Num }_{i t}-N u m_{e t}\right)+\alpha_{8} D s a m p+\alpha_{9} \operatorname{Tariff}+\mu
\end{aligned}
$$

Where, $\operatorname{Exp}_{i t}$, stands for China's tea exports to the 10 developed countries, is the dependent variable, data come from UNCTAD. $G n i_{e t}$ and $G n i_{i t}$ are the per capita gross national income (GNI) of China and importing countries, respectively. Since tea is healthy food, demand for tea will increase with the growth of China's per capita income, as well as the awareness of consumers' health consciousness; thus, the coefficient of variable $G n i_{e t}$ is expected to be negative. Data of these two variables are downloaded from database of World Bank, and have been processed by eliminating the effect of price and exchange rate fluctuations. Dis is the distance between capitals of China and its trade partners. The data are collected from the Centre d'Etudes Prospectives etd' Informations Internationales (CEPIIs). Prod stands for China's tea annual production, the large amount of production means abundant supply for export. In this paper, we use one-year lagged production to avoid potential endogenous problem. Data are from FAO database. Tariff denotes simple average tariff imposed on China's tea by the importing countries. Data are taken from the Trade Analysis Information System (TRAINS) of the UNCTAD. (Note 8)

Our key variables $\left(\mathrm{Fen}_{e t}-\mathrm{Fen}_{i t}\right)$ and $\left(\mathrm{Sul}_{e t}-\mathrm{Sul}_{i t}\right)$ are introduced to measure the difference of MRLs of chemicals between China and its partner countries. We subtract the fenvalerate and endosulfan MRLs of importing country $i$ from that of China respectively to measure the SPS gap in quality. If the difference is zero, it denotes that the common MRLs standard is implemented in both export and import countries, otherwise it means the control MRLs discrepancy. The positive difference represents that tea maximum residue limits set in China are less strict than that in developed countries. The larger the value is, the greater is the differences on control standards between China and developed countries, and China's exporters have to bear large cost of compliance and have less advantage in price, and therefore the total tea export will decline, i.e. a converse relationship exists. Strictly speaking, we should collect all the MRLs of chemicals on tea for accurate measurement. However, it's very difficult to get all pesticide standards over 1992 to 2013 for sample countries. What gratified is not all pesticide residues are inspected in trade, and only few of them play crucial role to affect trade. Fenvalerate and endosulfan MRLs fluctuate sharply and become reasons of China's tea being detained or rejected in importing countries. The data of the variables are collected from Global MRL database, the tea expert advisory system, the European Food Safety Net, Tea Research Institute and Fujian Academy of Agricultural Sciences. (Note 9)

$\left(N_{u m} m_{i t}-N u m_{e t}\right)$, the difference between MRLs number of developed countries and that of China, measures the SPS gap in quantity. If the value is positive, it means developed countries have more MRLs standards than China, China's tea exporters have to bear cost of compliance, and thereby the export will be easily subject to constraint. The relationship of these two variables is expected negative. The data of this variable are from the Tea-trading Net and China WTO/TBT-SPS Notification and Enquiry Net. (Note 10)

(Dsamp) denotes sampling method of residue detection. As a beverage, tea itself is not consumed directly; people drink the soup by diluting tea with boiled water. Therefore, traditional sampling method is taken from the soup, i.e. tea infusion. According to the characteristics of tea, the pesticide residues are diluted, and normally export tea is easy to be qualified. However, the EU and Japan adjusted their sampling method of residue from soup tea to dry tea, i.e. inspect the residue of tea itself in 1998 and 2006 respectively. The dry tea method significantly ascends the accurate rate of detection, and has more probability to detect the pesticide residue in tea. Therefore, a dummy variable is used to capture the sampling method on the China's tea export, and we set value as "0" if the sample is the soup tea or "1" when sample is taken from "dry tea" in developed countries, a negative relationship is expected. $\mu$ is the error term, used to capture the residue of missing variables. The descriptive statistics of the main variables in this model are shown in Table 1.

\begin{tabular}{|c|c|c|c|c|c|c|}
\hline Variable & Description & Mean & Std. Dev & Min & Max & Exp. Sign \\
\hline $\operatorname{Exp}$ & Export value $(10,000$ U.S.\$) & 1563.89 & 2131.67 & 5.46 & 10539 & + \\
\hline $\mathrm{GNI}_{\mathrm{et}}$ & GNI per capita of exp. countries (U.S.\$) & 2043.18 & 1807.71 & 370 & 6560 & + \\
\hline $\mathrm{GNI}_{\mathrm{it}}$ & GNI per capita of Imp. countries (U.S.\$) & 32935.14 & 10050.72 & 18560 & 65520 & + \\
\hline $\operatorname{Prod}_{\mathrm{t}-1}$ & A year-lag prod $(10 \mathrm{KT})$ & 91.50 & 35.70 & 57.60 & 171.49 & + \\
\hline Dist & Distance（Kilometer） & 8047.30 & 2295.24 & 2103 & 11172 & - \\
\hline $\mathrm{Fen}_{\mathrm{et}}-\mathrm{Fen}_{\mathrm{it}}$ & $\begin{array}{l}\text { Gap of chemical } 1 \text { between exp. \& imp. } \\
\text { countries (ppm) }\end{array}$ & -1.32 & 3.61 & -8 & 1.99 & - \\
\hline $\mathrm{Sul}_{\mathrm{et}}-\mathrm{Sul}_{\mathrm{it}}$ & $\begin{array}{l}\text { Gap of chemical } 2 \text { between exp. \& imp. } \\
\text { countries (ppm) }\end{array}$ & 3.23 & 12.08 & -20 & 29.99 & - \\
\hline $\mathrm{Num}_{\mathrm{it}}-\mathrm{Num}_{\mathrm{et}}$ & $\begin{array}{l}\text { Number gap of Standards betw. imp.\& } \\
\text { exp. countries }\end{array}$ & 96.07 & 86.90 & -19 & 267 & - \\
\hline Dsamp & Sampling method of residue & 0.47 & 0.50 & 0 & 1 & - \\
\hline Tariff & Simple average tariff $\quad(\%)$ & 1.95 & 3.54 & 0 & 14.58 & - \\
\hline
\end{tabular}

Table 1. Descriptive Statistics of Variable 


\section{Empirical Results}

First of all, we run the model by using OLS, country-specific fixed effect and random effect respectively. Compare the result of $\mathrm{F}$ test and Hausman test, it turns out that random effect is the best one. But it suffers from a lot of econometric issues. Among them the log-linearization of the variables can lead to biased estimations in presence of heteroskedasticity as stated by Santos Silva and Tenreyro (2006, 2011). They suggest using the Poisson Maximum Likelihood (PPML) method, which can help dealing with heteroskedasticity. Results show that the variables have expected signs and significant at $1 \%$ to $10 \%$ confidence level, which mean our estimations are reliable (see Table 2).

In all models, many of the estimated coefficients of the control variables have the signs that are intuitive. The signs, as well as the confidence levels, are robust even when using alternative econometric approaches (OLS, random-effect or PPML model). For example, the estimated coefficient for an importing country's GNI is positive and highly significant (at $1 \%$ level of statistical significance) in all columns, which means rising incomes in importing countries increase the countries' import demand for tea. Similarly, all coefficients for tea production variables are also significantly positive. The coefficients for distance variables have negative signs and statistically significant as expected. The coefficient of the tariff variable is also consistent across the different specifications of models except using the OLS estimation.

Table 2. The estimated results of gravity model

\begin{tabular}{|c|c|c|c|c|c|c|}
\hline & $\begin{array}{l}\text { OLS } \\
\text { (1) }\end{array}$ & $\begin{array}{l}\text { FE } \\
(2)\end{array}$ & $\begin{array}{l}\mathrm{RE} \\
(3)\end{array}$ & (4) & $\begin{array}{l}\text { PPML } \\
\text { (5) }\end{array}$ & (6) \\
\hline $\ln \left(\mathrm{GNI}_{\mathrm{ex}}\right)$ & $\begin{array}{l}-1.489^{\text {**** }} \\
(0.553)\end{array}$ & $\begin{array}{l}-1.233^{* * *} \\
(0.238)\end{array}$ & $\begin{array}{l}-1.218^{* * *} \\
(0.237)\end{array}$ & $\begin{array}{l}-1.243^{* * *} \\
(0.237)\end{array}$ & $\begin{array}{l}-0.543^{* * *} \\
(0.000)\end{array}$ & $\begin{array}{l}-0.556^{* * * *} \\
(0.000)\end{array}$ \\
\hline $\ln \left(\mathrm{GNI}_{\mathrm{im}}\right)$ & $\begin{array}{l}3.900^{* * * *} \\
(0.594)\end{array}$ & $\begin{array}{l}1.153^{* * *} \\
(0.340)\end{array}$ & $\begin{array}{l}1.158^{* * *} \\
(0.338)\end{array}$ & $\begin{array}{l}1.139^{* * * *} \\
(0.338)\end{array}$ & $\begin{array}{l}0.912^{* * * *} \\
(0.000)\end{array}$ & $\begin{array}{l}0.823^{* * *} \\
(0.000)\end{array}$ \\
\hline $\ln$ (Dist) & $\begin{array}{l}0.818 \\
(0.828)\end{array}$ & $\begin{array}{l}-- \\
--\end{array}$ & $\begin{array}{l}-4.270^{* * *} \\
(1.369)\end{array}$ & $\begin{array}{l}-4.529^{* * * *} \\
(1.354)\end{array}$ & $\begin{array}{l}-3.165^{* * * *} \\
(0.589)\end{array}$ & $\begin{array}{l}-3.222^{* * * *} \\
(0.592)\end{array}$ \\
\hline $\ln \left(\operatorname{Prod}_{t-1}\right)$ & $\begin{array}{l}2.142^{*} \\
(1.276)\end{array}$ & $\begin{array}{l}3.743^{* * *} \\
(0.550)\end{array}$ & $\begin{array}{l}3.709^{* * * *} \\
(0.548)\end{array}$ & $\begin{array}{l}3.801^{* * * *} \\
(0.545)\end{array}$ & $\begin{array}{l}2.173^{* * * *} \\
(0.000)\end{array}$ & $\begin{array}{l}2.255^{* * * *} \\
(0.000)\end{array}$ \\
\hline $\mathrm{Fen}_{\mathrm{et}} \mathrm{Fen}_{\text {it }}$ & $\begin{array}{l}-0.024 \\
(0.028)\end{array}$ & $\begin{array}{l}-0.021 \\
(0.016)\end{array}$ & $\begin{array}{l}-0.021 \\
(0.016)\end{array}$ & & $\begin{array}{l}-0.016^{* * * *} \\
(0.000)\end{array}$ & \\
\hline $\mathrm{Sul}_{\mathrm{et}}-\mathrm{Sul}_{\mathrm{it}}$ & $\begin{array}{l}-0.019^{* * *} \\
(0.008)\end{array}$ & $\begin{array}{l}-0.009^{*} \\
(0.005)\end{array}$ & $\begin{array}{l}-0.009^{*} \\
(0.005)\end{array}$ & $\begin{array}{l}-0.009^{*} \\
(0.005)\end{array}$ & $\begin{array}{l}-0.007^{* * * *} \\
(0.000)\end{array}$ & $\begin{array}{l}-0.007^{* * *} \\
(0.000)\end{array}$ \\
\hline $\mathrm{Num}_{\mathrm{it}}-\mathrm{Num}_{\mathrm{et}}$ & $\begin{array}{l}-0.006^{* * *} \\
(0.002)\end{array}$ & $\begin{array}{l}-0.008^{* * * *} \\
(0.001)\end{array}$ & $\begin{array}{l}-0.008^{* * *} \\
(0.001)\end{array}$ & $\begin{array}{l}-0.009^{* * * *} \\
(0.001)\end{array}$ & $\begin{array}{l}-0.006^{* * *} \\
(0.000)\end{array}$ & $\begin{array}{l}-0.006^{* * * *} \\
(0.000)\end{array}$ \\
\hline Dsamp & $\begin{array}{l}0.945^{* *} \\
(0.368)\end{array}$ & $\begin{array}{l}0.651^{* * * *} \\
(0.166)\end{array}$ & $\begin{array}{l}0.649^{* * * *} \\
(0.165)\end{array}$ & $\begin{array}{l}0.579^{* * * *} \\
(0.156)\end{array}$ & $\begin{array}{l}0.237^{* * * *} \\
(0.000)\end{array}$ & $\begin{array}{l}0.194^{* * * *} \\
(0.000)\end{array}$ \\
\hline Tariff & $\begin{array}{l}0.269^{* * *} \\
(0.106)\end{array}$ & $\begin{array}{l}-0.362^{* * *} \\
(0.102)\end{array}$ & $\begin{array}{l}-0.336^{* * *} \\
(0.100)\end{array}$ & $\begin{array}{l}-0.366^{* * *} \\
(0.0978)\end{array}$ & $\begin{array}{l}-0.280^{* * * *} \\
(0.000)\end{array}$ & $\begin{array}{l}-0.286^{* * * *} \\
(0.000)\end{array}$ \\
\hline cons & $\begin{array}{l}-50.91^{* * *} \\
(14.68) \\
\end{array}$ & $\begin{array}{l}-37.36^{* * * *} \\
(5.927) \\
\end{array}$ & $\begin{array}{l}0.990 \\
(12.81)\end{array}$ & $\begin{array}{l}2.577 \\
(12.75) \\
\end{array}$ & $\begin{array}{l}10.40^{* *} \\
(5.261)\end{array}$ & $\begin{array}{l}10.85^{* *} \\
(5.288)\end{array}$ \\
\hline Observations & 220 & 220 & 220 & 220 & 220 & 220 \\
\hline R-squared & 0.516 & 0.607 & 0.607 & 0.604 & 0.728 & \\
\hline $\begin{array}{l}\text { F Test } \\
\text { Hausman Test }\end{array}$ & $\begin{array}{l}F=121.27 \\
-\end{array}$ & $\begin{array}{r}(\mathrm{p}=0.000) \\
\mathrm{H}=3.08\end{array}$ & - & & & \\
\hline
\end{tabular}

Note:*,**and***indicate significance at the levels of $10 \%, 5 \%$ and $1 \%$ respectively.

The variable of number difference of MRLs is significant at $1 \%$ confidence level in all five models, and the regression coefficient is -0.006 , suggesting that number of MRLs of chemicals of developed countries is larger by one unit than that in China, China's tea export would correspondingly decrease by $0.6 \%$. The significant result shows that the difference in numbers of SPS measures between China and developed countries will affect China's tea export; i.e. SPS gap in quantity will constrain China's tea export. By now, the first hypothesis of this paper has been verified.

In May 2001, Japan enacted new standards on tea, which added the items of tea pesticide residue limits from 24 in 1992 to 76, then to 276 since the implementation of the Positive List System in 2006. Prior to 2000, the number of pesticide residue limits of tea in the EU was only 62, and then it increased to 134 in 2000, 193 in 2003, and further to 227 in 2007. Meanwhile, China has been also endeavoring to improve its domestic pesticide residue limits standards as the developed countries did. Since 2009, the number of MRLs of food has increased to 2319, among which, the MRLs for tea has also reached 27. However, the difference in number of MRLs, or quantity gap between China and developed countries is widening. Because of these enlarging differences, some pesticides are regulated or controlled or even banned in developed countries may have not been restricted or controlled in China yet, which directly stop China's tea export to developed countries. As shown in figure 6, with the quantity gap widening, the volume ratio of China's tea export to EU and Japan in China's total export declines, with an inverse relationship.

Meanwhile, the negative sign and statistical significance of SPS difference of endosulfan and fenvalerate MRLs support that SPS gap in quality will constrain China's tea export. The estimated coefficient of fenvalerate suggests the 
difference of fenvalerate MRLs between China and developed countries shrinks by $1 \mathrm{ppm}$; China's tea export would increase correspondingly by $1.6 \%$ (column (5), Table 2). The estimated coefficient of endosulfan is 0.007 in the PPML model, which means, on the margin, a 1ppm decrease in the difference of endosulfan MRLs between China and developed countries will raise bilateral tea trade by approximately $0.7 \%$. One possible explanation for why the impact of the MRLs of endosulfan is smaller is that the EU reset its MRLs of endosulfan in tea from $0.01 \mathrm{ppm}$ back to the Codex level $(30 \mathrm{ppm})$ in 2007 after being executed for less than two years because of the opposition of exporting countries including China. By now, the second hypothesis of this paper has been proved.
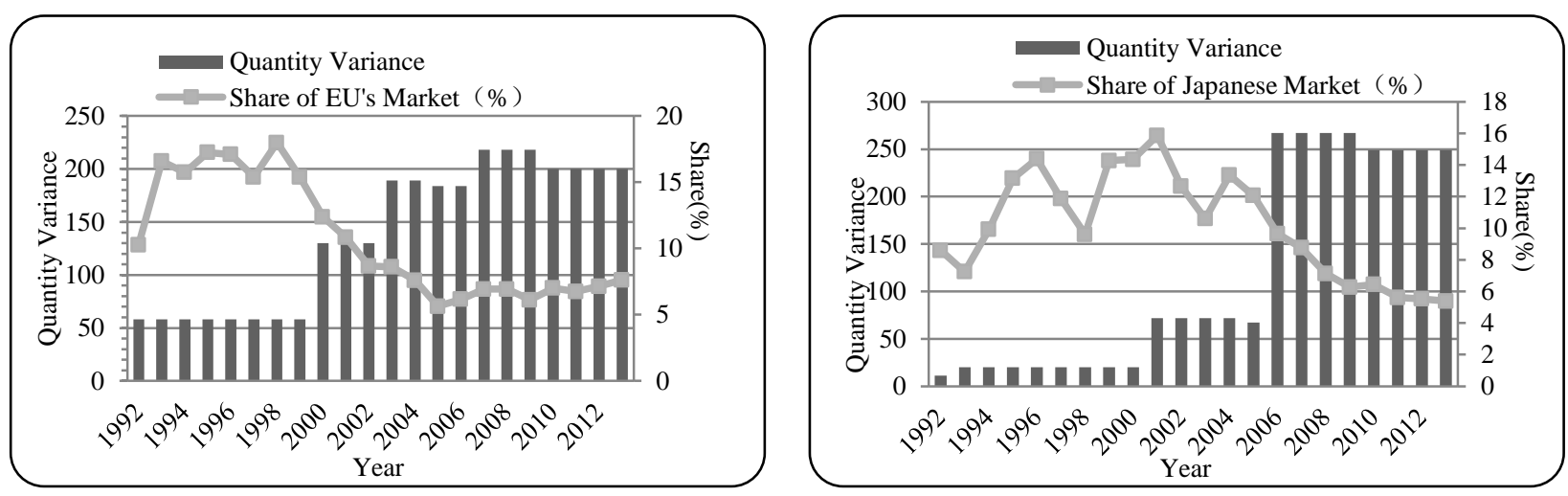

Figure 6. The number difference of pesticide residue limits standards between China and foreign countries and the share of EU's

and Japanese market of China's tea export during 1992 to 2013.

Data source: UN Comtrade Database (http://comtrade.un.org/data)

Dummy variable Dsamp (sampling method of residue detection) is significant at the $1 \%$ confidence level, but its regression coefficient is positive, which is not accordant with the expectation. One possible reason is only small size of samples used in this paper. Another potential reason is only small amount of tea export to the developed countries which use dried-tea sampling method.

\section{Conclusion and Policy Implication}

China is the world largest tea producer, as well as a major exporter. With the execution of the "agricultural agreement" and the "SPS agreement" signed in the Uruguay round negotiations, the tariff level of tea has fallen sharply, while SPS measures in WTO members, particularly the developed countries, tended to be stricter, in a form of the rising number of MRLs and the more stringent requirement of pesticide residue limits. Although China also improves its SPS standard for tea constantly, the gap of the SPS measures between China and developed countries is widening either in quality (i.e., the level of pesticide residue limits) or quantity (i.e., the number of pesticide residue control standards). As a result, China's tea export price goes down, and the export market has been shifting from developed countries to developing countries. Based on data of China and its 10 developed trade partner countries during 1992 to 2013, this paper applies gravity model to investigate the influence of the discrepancy of SPS measures in quantity and quality between China and developed countries on China's tea export. The empirical results show that while the differences of Maximum Residual Limits of fenvalerate and endosulfan between China and developed countries increases by $1 \mathrm{ppm}$, China's tea export would correspondingly decrease by $1.6 \%$ and $0.7 \%$, respectively; while the differences of regulated number of pesticide residue limits between China and developed countries increases by 1 unit, China's tea export would correspondingly decrease by $0.6 \%$. The differences in SPS measures both in quality and quantity are the main determinants of China's tea restricted by the SPS measures in developed countries.

Based on the results, the policy implication is obvious. For the sustainable development of China's tea, it would be better for China focus on the control of pesticide residues, striving to narrow the differences of pesticide residue control standards of tea in quality and quantity between China and developed countries. First of all, it should abolish the overlapped or old standards, increase the coverage of regulated pesticides and refine the MRLs, to reduce the number differences in standards with that of developed countries. Secondly, risk assessment of hazard and harmful material in tea should be the core of any revision at national level or industry level, or for setting up new SPS standards. For export firms, reform proactively their production technology and adopt the standards of international core markets to promote the tea quality. In addition, China must voice in the formulation of international standards. China's green tea exports accounts for 3/4 of the exports of China's tea. Therefore, authorities departments must strengthen the risk assessment of the toxicity of pesticide residue in tea, and participate in activities of international organizations such as OIE, Codex and 
IPPC proactively. If the tea standards of China are accepted by most countries and became the Codex standards, it will greatly facilitate China's tea export.

\section{Acknowledgements}

The research is supported by National Natural Science Foundation of China (Grant No.71373154) and Shanghai Pujiang Talent Program (Grant No. 15PJC048). The authors would like to thank Xiao Chu for data collection and professor Mingque Ye for help in empirical work.

\section{References}

Anders, S., \& Caswell, J. A. (2009). Standards-as-barriers versus Standards-as-catalysts: Assessing the Impact of HACCP Implementation on U.S. Seafood Imports, American Journal of Agricultural Economics, 91(2), 310-321. http://dx.doi.org/10.2139/ssrn.986616

Chen, C. Yang, J., \& Findlay, C. (2008). Measuring the Effect of Food Safety Standards on China's Agricultural Exports, Review of World Economic, 144(1), 83-106. http://dx.doi.org/10.1007/s10290-008-0138-z

Disdier, A., Fontagné, L., \& Mimouni, M. (2008). The Impact of Regulations on Agricultural Trade: Evidence from SPS and TBT Agreements, American Journal of Agricultural Economics, 90(2), 336-350. http://dx.doi.org/10.2139/ssrn.1194969

Dong, Y. (2011). Positive Analysis of the Effect of SPS Measures on China's Aquatic Product Export. Chinese Rural Economy, 2, 43-51.(in Chinese).

Dong, Y., \& Jiang, P. (2012). On the Determinant Factors of Agricultural Export Enterprises in China Impacted by SPS Measures, Journal of International Trade, 11, 145-155. (in Chinese).

Drogué, S., \& DeMaria, F. (2012). Pesticide residues and trade, the apple of discord?, Food Policy, 37(6), 641-649. http://dx.doi.org/10.1016/j.foodpol.2012.06.007

Gu, G., \& Niu, X. (2007). Empirical Study on the Impacts of Technical Barrier to Trade on International Trade-Taking Tea Trade between China and Japan as an Example, Journal of International Trade, 6, 74-80. (in Chinese).

General Administration of Quality Supervision, Inspection and Quarantine of the People's Republic of China (AQSIQ). (2009, 2012). The Annual Report of China's Technical Trade Measures 2009 The Annual Report of China's Technical Trade Measures 2012.

Henson, S., \& Heasman, M. (1998). Food Safety Regulation and the Firm: Understanding the Compliance Process, Food Policy, 23 (1), 9-23. http://dx.doi.org/10.1016/s0306-9192(98)00015-3

Henson, S., \& Humphrey, J. (2010). Understanding the Complexities of Private Standards in Global Agri-Food Chains as They Impact Developing Countries, Journal of Development Studies, 46(9), 1628-1646. http://dx.doi.org/10.1080/00220381003706494

Henson, S., Masakure, O., \& Boselie, D. (2005). Private Food Safety and Quality Standards for Fresh Produce Exporters: The Case of Hortico Agrisystems Zimbabwe, Food Policy, 30(4), 371-384. http://dx.doi.org/10.1016/j.foodpol.2005.06.002

Jongwanich, J. (2009). The Impact of Food Safety Standards on Processed Food Exports from Developing Countries, Food Policy, 34(5), 447-457. http://dx.doi.org/10.1016/j.foodpol.2009.05.004

Li, X. (2014). The Effects of Food Safety Standards on Trade and Welfare: The Case of EU Shrimp Imports, Agricultural Economics, Paper 30.

Liu, L., \& Yue, C. (2012). Investigating the Impact of SPS Standards on Trade Using a VES Model, European Review of Agricultural Economice, 39(3), 511-528. http://dx.doi.org/10.1093/erae/jbr036

Manarungsan, S., Naewbanij, J. O., \& Rerngjakrabhet, T. (2005). Costs of Compliance with SPS Standards: Thailand Case Studies of Shrimp, Fresh Asparagus and Frozen Green Soybeans, World Bank Agriculture and Rural Development Discussion Paper Washington DC: World Bank, 1-62.

Maskus, K. E., Otsuki, T., \& Wilson, S. (2005). The Cost of Compliance with Product Standards for Firms in Developing Countries: An Econometric Study. http://dx.doi.org/10.1596/1813-9450-3590

Moenius, J. (2004). Information versus Product Adaptation: The Role of Standards in Trade. http://dx.doi.org/10.2139/ssrn.608022

Neeliah, S., \& Goburdhun, D. (2010). Complying with the Clauses of the SPS Agreement: Case of a Developing Country, Food Control, 21(6), 902-911. http://dx.doi.org/10.1016/j.foodcont.2009.12.008

Otsuki, T., \& Wilson, J. (2001). Saving Two in a Billion: Quantifying the Trade Effect of European Food Safety 
Standards on Afraican Exports, Food Policy, 26(5), 495-514. http://dx.doi.org/10.1016/s0306-9192(01)00018-5

Qin, Z., \& Ni, Y. (2013). An Empirical Study of the Impact of Technical Trade Barriers on China's Agricultural Exports since the Establishment of WTO Based on the Two-stage Gravity Model of Multilateral Resistance, International Economics and Trade Research, 1, 35-47. (in Chinese).

Robert, D., Orden, D., \& Josling, T. (1999). A Framework for Analyzing Technical Barrier in Agriculture Market, Technical Bulletin 1876, Market and Trade Economics Division, U.S. Department of Agriculture.

Santos-Silva, J. M. C., \& Tenreyro, S. (2006). The log of gravity, The Review of Economics and Statistics, 88(4), 641658. http://dx.doi.org/10.2139/ssrn.380442

Santos-Silva, J. M. C., \& Tenreyro, S. (2011). Further simulation evidence on the performance of the poisson pseudo-maximum likelihood estimator, Economics Letters, 112(2), 220-222. http://dx.doi.org/10.1016/j.econlet.2011.05.008

Sun, D., Sun, W., \& Zhou, J. (2007). The Impacts of EU's MRL Standard on China's Tea Exports, Journal of Agricultural Technical Economics, 1, 63-71. (in Chinese).

Trienekens, G., \& Zuurbier, P. (2008). Quality and Safety Standards in the Food Industry Developments and Challenges, Production Economics, 113(1), 107-122. http://dx.doi.org/10.1016/j.ijpe.2007.02.050

Wei, G., Huang, J., \& Yang, J. (2012). The Impact of Food Safety Standards on China's Tea Exports, China Economic Review, 23(2), 253-264. http://dx.doi.org/10.1016/j.chieco.2011.11.002

Wilson, J., \& Otsuki, T. (2004). To Spray or Not to Spray: Pesticides, Banana Exports and Food Safety, Food Policy, 29 (2), 131-146. http://dx.doi.org/10.1016/j.foodpol.2004.02.003

Xiong, B., \& Beghin, J. C.(2011). Disentangling the Demand-enhancing Effect and Trade-cost Effect of Technical Measures in Agricultural Trade among OECD Countries. http://dx.doi.org/10.2139/ssrn.1945235

Xu, Y., \& Gao, Q. (2006). Positive Analysis of the Effect of Technique Barriers on China's Tea Export, Journal of International Trade, 5, 86-93. (in Chinese)

Zou, H., \& Feng, Z. (2009). The Change Trend and Positive Analysis of Effect of China's Tea Export Trade, Statistics and Decision, 3, 77-79. (in Chinese)

\section{Notes}

Note 1. The data are estimated according to the TRAINS database of WTO (http://stat.wto.org)

Note 2. According to the requirement of WTO / SPS agreement, all the members have to notify the newly established SPS measures or amendments to the initial measures. The data are collected from the SPS-IMS database of WTO (http://spsims.wto.org).

Note 3. According to SPS agreement, SPS measures are regulations, standards, methods and requirements, including the processing and production methods, testing, inspection, and certification and approval procedures, quarantine treatment, statistics, sampling and risk assessment methods, as well as packaging and labeling requirements directly related to food safety, animal and plant health and environment safety.

Note 4. The data are collected from the WTO-TBT / SPS notification center of AQSIQ (http://www.tbt-sps.gov.cn).

Note 5. Source: data in this section are calculated according to the data of Chinese tea production in FAO database (http://www.fao.org/statistics).

Note 6. Source: United Nations Trade Database UNCTAD (http://unctadstat.unctad.org).

Note 7. Data in this section is calculated according to the trade data of China's importers in United Nations Trade Database (http://unctadstat.unctad.org).

Note 8. Data in this section come from UNCTAD (http://unctadstat.unctad.org), World Bank database (http://data.worldbank.org), CEPIIs (http://www.cepii.fr/CEPII/en/), and FAO database (http://www.fao.org/statistics). The interval of production data in model is $1991 \sim 2010$. 
Note 9. Data in this section are collected from Global MRL database (https://www.globalmrl.com/), the tea expert advisory system (http://www.scnjkj.gov.cn), the European Food Safety Net (http://www.efsa.europa.eu) and Tea Research Institute and Fujian Academy of Agricultural Sciences (http://www.faas.cn).

Note 10. Data in this section are collected from Tea Trade Net (http://www.tea-trading.com ) and China WTO-TBT/SPS Notification Center Net ( http://www.tbt-sps.gov.cn).

\section{(cc) EY}

This work is licensed under a Creative Commons Attribution 3.0 License. 